\title{
Research on Life View Education Approaches of College Students
}

\author{
Ling Rong \\ China West Normal University \\ Nanchong, China \\ 54812679@qq.com
}

\begin{abstract}
University stage is an important period to shape college students' life view. In recent years, college students have unclear understanding on themselves and life, and they are lack of correct understanding on life value. Positive life view is not comprehensively formed. Currently, life view education becomes the research hotspot of education in colleges and universities. Many scholars deeply study connotation and origin of life view education as well as the cause, current situation and approach of life view education. On the basis, approaches of life view education of college students are studied in the paper. Life view education contents of college students are mainly described. Current situation of college students' life view education is analyzed. Approaches for reinforcing college students' life view education are proposed. In the paper, it is believed that colleges and universities should implement life view education courses in various forms. Professional teacher teams and course construction can be reinforced. Cognition of life can be strengthened for setting up correct life view education idea; colleges should attach great importance to social education and build a harmonious society. Recognition of college students on life can be promoted to form correct life view and drive harmonious development of society.
\end{abstract}

Keywords-colleges and universities; college students; life view education; approach

\section{INTRODUCTION}

In recent years, college students commit suicide and are killed by others frequently, which draws attention from all the society. These events show that Chinese college students are indifferent to life and do not cherish life. College students are in the stage of late youth and early adulthood, which belongs to self-adjustment period. In the period, college students can obtain the most fundamental and most representational perception on life through experiencing own life growth. They can comprehend value and significance of life through university education and life practice, thereby preliminary views to life. College students can involve in rational thinking at higher level, but they should think about life meaning and life value. University education has ultimate goal of all-round development of people, which is acted on people's spiritual world. Education process does not merely aim at imparting skills and knowledge. More importantly, it should guide students to think about life value, discover life value and cherish life. Life is the foundation for human survival. College education will lose its basis of existence and development without life. Therefore, colleges and universities should pay much attention to education of college students' life view. College students can realize meaning of life existence, cherish and respect life value, and adapt to social life, which cultivates comprehensive development of college students, and realizing life value.

\section{CONTENTS OF COLLEGE STUDENT LIFE VIEW EDUCATION}

\section{A. Life existence value education}

Life is unique for everyone, which has very special meaning to the objective world. Human beings are social individuals. Existence relationship is available between individuals and groups as well as among individuals. Social attributes are unique, exclusive and irreplaceable. Colleges and universities should properly guide college students to cherish life existence value, and cultivate rational and correct life values.

\section{B. Life contribution value education}

Life is not just alive. It is the most superficial significance of life. Currently, college students do not attach importance to life contribution value. Many students only recognize superficial meaning of life, and do not recognize that own life can be realized for life. Creation of social value is the more noble value of life. Life value can be realized through social practice. Life value lies in creating value greater than life itself.

\section{Death view education}

Death view value is one of important contents of life view education. Everyone has different understandings on life and death. Different fields have different understandings on life and death. Death view education includes life view education, happiness education, career view education, frustration education, career education and faith education, etc. It is required in death view education that modern college students can have more correct understanding on death, and they can realize that death is the ultimate embodiment to achieve perfect life. It is endpoint of life of people. Death view education in colleges and universities can promote college students to correctly recognize death view, thereby cherishing life and paying attention to expand life breadth and width.

\section{Frustration education and adversity education}

Life cannot be always smooth. Life is complete if people can hold up in failure and experience hardship. It is urgent for colleges and universities to implement frustration and adversity education. College students' frustration education can be reinforced, and thereby they can achieve correct understanding on frustration, and 
search for measures to solve setbacks. Students can correctly treat setbacks and solve setbacks.

\section{ANALYSIS ON CURRENT SITUATION OF COLLEGE STUDENTS' LIFE VIEW EDUCATION}

\section{A. Colleges and universities do not attach enough importance to life view education, and complete system is not formed}

China colleges and universities rarely implement life education, and pay less attention on life education. More complete system is not formed. In the paper, life education of students in one university is implemented, the survey results are shown in Fig. 1 and Fig. 2. Fig. 1 shows that colleges and universities implement life education is mainly through penetrating life education in ideological and political theory courses, accounting for $34 \%$ of life education. There are only $6.2 \%$ of colleges and universities implement special life education curriculum; $18.9 \%$ colleges and universities penetrate life education in mental health education curriculum; $7.7 \%$ universities and colleges embody life education in campus culture, and remaining universities and colleges account for $33.2 \%$. It is obvious that life education courses are less without specific life education curriculum. Fig. 2 shows that college students have the highest interest in humanities lectures among life view education elective courses, accounting for $29.7 \%$ of total population. It is followed by life philosophy, accounting for $20.9 \%$; mental health course accounts for $15.6 \%$. It is obvious that Chinese college students are more interested in life value. However, current life view education in colleges and universities cannot meet the demands of students. It is obvious that colleges and universities fail in forming better trading system aiming at life education of college students. Life view education view is not mature.

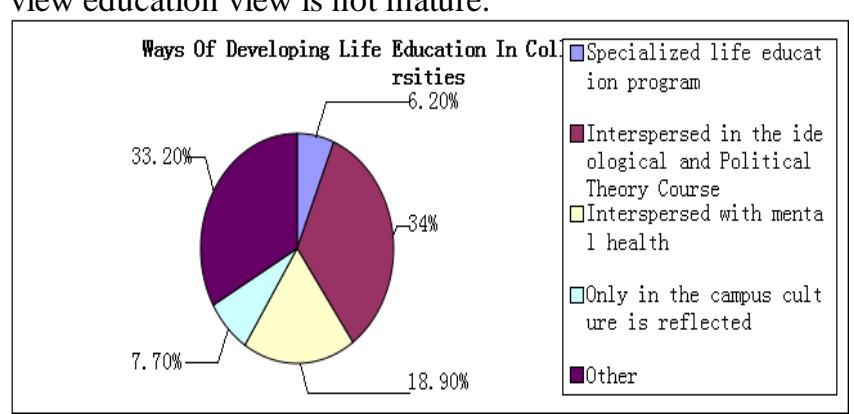

Figure 1. Life view education mode of colleges and universities

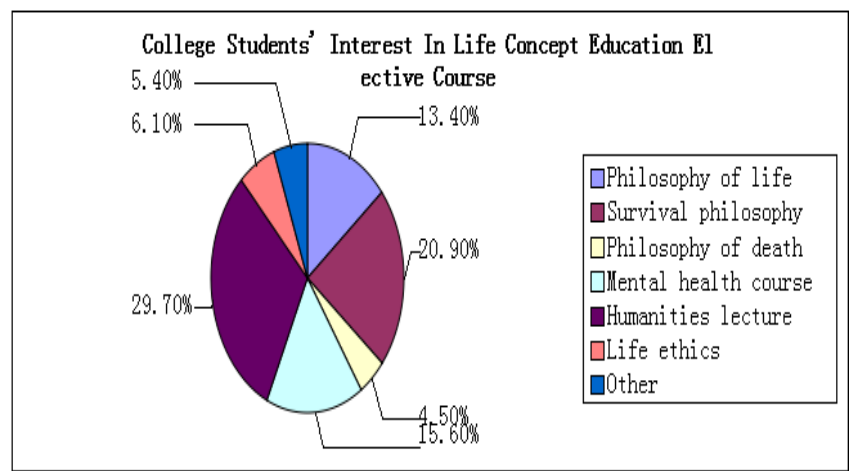

Figure 2. Interested life view education elective courses of college students

\section{B. Resources in the field of life education are in short supply}

Many colleges and universities implement a series of psychological education curriculum for students. However, teaching in the aspect of life view education is rare. Most teaching materials are old, which cannot keep up with the development of modern society seriously. It cannot produce psychological resonance with modern college students. Proper effect of life view education cannot be easily exerted. In addition, a professional teacher team is required for colleges and universities to implement life view education work. However, colleges and universities in China are provided with few professional teachers for life view education. China focuses on teaching professional knowledge and skills. Research on ideological education and psychological education is less. It is still in the primary exploring stage and lack of professional teacher resources. Many life teachers in colleges and universities are still in the learning stage, and implement life view education through lecture mode. It is difficult to deepen into life essence without excellent education effect.

\section{Professional education is emphasized, and life view education is lack of correct understanding}

People pay more and more attention to professional level with society progress and development of science and technology level. University education is more deviated to improving students' professional knowledge and professional skills. Modern college education belongs to typical technical education. China college education becomes more and more utilitarian under the influence of market economy. Education aims at allowing students to graduate smoothly and achieve good jobs without cultivation on college students' cultural background. College students not only should accept professional knowledge learning, but also should help college students to feel goodness of life in colleges and universities. They have deeper understanding of life in order to realize life value and life ideal. Currently, China colleges and universities are lack of understanding on life education. College students do not have deep comprehension on life. Therefore, Chinese college students commit suicide frequently, and it is the manifestation that students are lack of correct understanding on life view.

\section{APPROACHES TO STRENGTHEN UNIVERSITY STUDENTS' LIFE VIEW EDUCATION}

In life view education, students should be educated for cherishing and respecting life, and increasing understanding of life. Therefore, physical and mental health of college students can be harmonious developed with colleges and universities. Life view education should be gradually developed according to college students' own demands and time development demands. Colleges and universities should implement life view education from the following aspects according to practical condition and life contents of modern college students.

\section{A. Implementation of life view education curriculum in various forms}

College students' ideological situation should be comprehended more deeply in order to receive certain education achievement for college student education. Life 
view education in various forms can be implemented. Life view education can be implemented from two aspects of direct education and infiltration education. Students can theoretically and systematically accept life view education in direct education through setting up life view education course. Various topic seminars, topic discussion, communication meetings, etc. about life view are implemented. Therefore, college students can reinforce life view exchange and deepen understanding on life. Infiltration education mainly refers that various social practice activities are implement for practical life view education mainly based on campus culture activities. For example, students can explore own potential through organizing various competitions or culture festival activities, thereby enhancing social sense of responsibility, and cultivating optimistic and positive life concept. More chances to contact the society can be given to college students. Students should participate in social practical activities about life activities and sufficiently understand significance of life existence and life created by human life, thereby recognizing life importance, respecting life, widening life width and realizing life value.

\section{B. Strengthening of professional teacher and curriculum construction}

Life view education of colleges and universities lies in professional educators. Life education should not be only limited to teaching materials. Life view education of college students can achieve better effect through scientific lire view education system, guidance of professional teachers as well as the professional and rich teaching resources. It can actually assist college students to recognize meaning and value of life. College students can be guided for establishing correct life view. However, life view education is rarely taken currently in China. It is difficult for professional books and professional teachers to meet the demands of college students on life view education at present. Insufficient professional teacher is a serious problem to limit life view education in colleges and universities. Therefore, China should strength related research on life view education, and increase construction of life view education teacher teams. Special life view education course should be implemented in colleges and universities. Life view education quality of college students in China can be improved.

\section{Strengthening of life cognition, and establishment of correct life view education concept}

Students' cognition on life should be strengthened in college education. They should establish correct life education concept. Life should be comprehended more deeply before establishment of life concept. Therefore, the significance of life existence should be recognized firstly. Life existence is fundamental, unique, irreplaceable and irreversible. Maintenance of life existence should be regarded as the first principle of life activities. Secondly, it should be realized that life existence is only basis of human existence rather than the final purpose of human existence. Life existence should embody its social value. Life significance can be achieved by creativity thereof. Life acts as material carrier of human existence. It is materials foundation for people to survive and realize life value and significance. All discussions about people are nothing without the foundation. Therefore, human beings do not refer to existence of life itself only, which also indicates existence of life spiritual significance level. These are foundational conditions for college life view education of life recognition. Therefore, correct life view education concept can be established in the process of implementing life view education on college students. College student life and mental world can be more focused on. Students can be cultivated to respect basic significance and esteem of life. The most significance part lies in understanding life value and significance as well as life spirit significance so as to improve their life consciousness.

\section{Emphasis on social education, and construction of harmonious society}

Life view education of college students should be strengthened. Social education also should be focused. Life harmony is the foundation of all activities. It is the basis for constructing harmonious society. In real life, social forces should be depended on for increasing effectiveness, pertinence and scientific nature of life education. A good social situation can be formed, and therefore the society can further cherish life, respect life, and promote harmonious and healthy development of society. Life view education micro-course can be constructed in microsociety. Mass media can be utilized for spreading related life view education concept and implementing activities in related forms. Life meaning education and propaganda can improve life view education consciousness of the public, and expand life view education class and scope. The whole society should be mobilized for jointly setting up "safety net" for some poor information. A good social environment can be created for their healthy growth. College students should be educated for consciously rejecting unreasonable material comforts, pursuing higher spiritual enjoyment, strengthening correct public opinion direction, setting up correct life view, and changing taboo recognition in traditional concept on death. People can live in a social environment with deep cultural atmosphere. An atmosphere respecting, revering and cherishing life can be created in the whole society.

\section{E. Implementing death education, and strengthening life consciousness of college students}

People always think that death is a taboo word due to the influence of Chinese traditional thought. Death is rarely considered. Though everyone knows that death is the end of life, people don't like to discuss it. In fact, life is always accompanied by death. Life and death are opposite. Birth and death are a part of life. Life view education of colleges and universities on college students should include death education. Death education refers that students are educated to form a more reasonable life wisdom and attitude to life so as to improve life trait and life quality. Death education can promote students to consider life and death, and help college students escape from the fear of death, improve their awareness and alert of life, consider and experience life significance again, promote college students to further cherish life, and improve the life value.

\section{SUMMARY}

Social competition is intense in China at present with high employment pressure. Contemporary college 
students encounter high survival pressure, and assume much social pressure. College education workers should be responsible for paying more attention to life, learning and mental state of college students. Life view education of college students is demand for era development and mental requirement of college students. Mental condition of college students should be combined for comprehensive consideration. Life view education of college students should be strengthened for deeply comprehending life essence and survival cognizance, expanding life connotation, and promoting college students to pursue life significance at higher level. In the paper, it is believed that China universities and colleges should implement life view education courses in diversified forms. Professional teacher team and course construction should be reinforced. Life recognition should be strengthened. Correct life view education concept should be established. Social education should be emphasized for constructing harmonious society.

\section{REFERENCES}

[1] Li Deling, Han Feizhou. Li Yiting. "Overview on research situation of life view education of college students," Health Vocational Education, vol. 9, 2011 , pp. 26-27.

[2] Xu Lili, LIU Yanhua, Jiang Xiaojuan. "Investigation on the current situation of college students' life view and analysis on countermeasures," Education Science \& Culture Magazine (midmonth version), vol. 1,2012, pp. 78-80.

[3] Zhang Jiutao, Liu Ying, Zhang Chunli. "On significance and implementation methods of college students' life view education," Chinese Health Service Management, vol. 9, 2012, pp. 129-130;

[4] Cui Xiaona. "Introduction to current situation and approaches of college students' life view education," Journal of Hainan Normal University (Social Science Edition), vol. 1, 2013, pp. 82-84.

[5] Tao Jinhua, Tian Fang, Li Na. "College students' life view current situation and life education approaches," Journal of Yichun University, vol. 10, 2011, pp. 33-34.

[6] Wu Jing. "Investigation of contemporary college students' life view and research on life education," China Adult Education, vol. 5, 2010, pp. 14-17.

[7] Wang Lihua. "On focuses of life view education of college students born after '1990s'," School Party Construction and Ideological Education, vol. 2, 2011, pp. 111-113.

[8] Zhang Xiang. "On life view concept education of contemporary college students," Journal of Shanxi Radio TV University, vol. 1, 2012, pp. 54-56.

[9] Zhu Meng. "Research status, problems and countermeasures of college students' life view education," Ideological and Political Education Research, vol. 1, 2012, pp. 90-92.

[10] Yu Hua. "On enlightenment of Zhang Side's life view on contemporary college students," Mao Zedong Thought Research, vol. 4, 2013, pp. 14-16. 